\title{
Dissipation of Pheromone from Dispensers of Specialized Pheromone and Lure Application Technology (SPLAT-PBW) Formulation used against Pink Bollworm, Pectinophora gossypiella (Saunders) (Lepidoptera: Gelechiidae) in Bt Cotton Ecosystem
}

\author{
Shrinivas $^{1 *}$, A.G. Sreenivas ${ }^{1}$, S.G. Hanchinal ${ }^{1}$, Sujay Hurali ${ }^{1}$ and R.V. Beldhadi ${ }^{2}$ \\ ${ }^{1}$ Department of Agricultural Entomology, ${ }^{2}$ Department of soil science and agricultural \\ chemistry, UAS Raichur- 584 104, Karnataka, India \\ *Corresponding author
}

A B S T R A C T

\section{Keywords}

Pheromone,

Dispensers,

Pink Bollworm,

Pectinophora

gossypiella

Article Info

\section{Accepted:}

18 January 2019

Available Online:

10 February 2019
The gelechiid Pectinophora gossypiella (Saunders) is a limiting factor in Bt cotton production and has been reported to cause locule damage to an extent of 55 per cent and reduction in seed cotton yield in the range of 35- 90 per cent (Narayanan, 1962). By and large, pesticides are used as a major weapon for combating this pest damage. In India, total insecticides used to control bollworms alone were 9410 MT in the year 2003-04, worth of 747.6 crores (Kranthi, 2012). Despite such a high proportion of pesticide consumption, pink bollworm pressure could not be contained rather have made the situation worse by development of resistance to major insecticides and $B t$ toxins. Now there is a need to shift from traditional management practices to a novel technique called Specialized Pheromone and Lure Application Technology (SPLAT-PBW) against PBW in Bt cotton ecosystem which has rain fastness, easy to apply, long lasting properties and cost effective. So as to assess its feasibility in $B t$ cotton, dissipation studies were carried out by collecting filed samples of SPLAT-PBW dispensers at weekly interval and were subjected to gas chromatography analysis, wherein the results revealed that even by the end of fifth week 40.36 percent of active ingredient i.e. pink bollworm pheromone ((ZZ/ZE) 7, 11Hexadecadienly acetate) was left in the samples collected which, clearly indicates the slow release mechanism of SPLAT-PBW compared to other lures.

\section{Introduction}

Cotton is the most important commercial crop grown for fiber, fuel and edible oil under diverse agro-climatic conditions. It provides a source of livelihood and employment to millions of farmers, farm workers and persons employed in related industries.
The crop is cultivated in more than 100 countries in 32 million hectares (Anon., 2015). Earlier, in non $B t$ cotton, the infestation of pink bollworm caused 2.8 to 61.9 per cent loss in seed cotton yield, 2.1 to 47.10 per cent loss in oil content and 10.70 to 59.20 per cent loss in normal opening of bolls (Patil, 2003). 
The pink bollworm Pectinophora gossypiella (Saunders) (Lepidoptera: Gelechiidae) is one of the most important destructive pests of cotton and is distributed throughout the world's cotton-growing areas causing maximum seed cotton loss in quantity and quality (Pearson, 1958). PBW is emerging as a serious pest and its activity is observed for a brief period from January to till the end of the season in April. In the recent past, the pest has been frequently noticed from early flowering. Soon after emergence, the PBW larvae enter the fruiting body. As a result, farmers remain totally ignorant about the damage caused by PBW till the boll opening and hence could not exercise any target specific control measures against the pest.

Total insecticides used to control bollworms alone were $9410 \mathrm{MT}$ in the year 2003-04, worth of 747.6 crores (Kranthi, 2012). So, to avoid the pesticides problem of bollworms on cotton, it was modified transgenically as $B t$ cotton and was released for commercial cultivation in India during march 2002 (Choudhary and Gaur, 2015). Insecticidal proteins of the bacterium Bacillus thuringiensis that are produced in the transgenic crop plants can reduce reliance on sprayed insecticides (Shelton et al, 2002). B. thuringiensis toxins kill some major crop pests, but compared with broad-spectrum insecticides, they are less harmful to nontarget organisms, including beneficial insects, wildlife, and people (Charles et al, 2000). In the $B$. thuringiensis crops (cotton, corn, and potato) grown commercially so far, each individual plant produces only one type of $B$. thuringiensis toxin. These first-generation $B$. thuringiensis crops, which have been used on a large scale since 1996, occupied more than 11 million hectares worldwide in 2000 (James, 2000).

Quite long time (almost 10 years) Bt cotton could able to protect crop from bollworms whereby, reducing the pesticide usage from
$46 \%$ to less than $21 \%$ (Kranthi, 2013) and increased the yield of Indian cotton growers by 82 per cent (Kranthi, 2012). Off late, since three to four years or so, pink bollworm, $P$. gossypiella has aggravated as it has developed resistance to insecticides ( $\mathrm{Li}$ et al., 1997; Sabry and Nahed, 2013) and to cry toxin of $B t$ cotton (Tabashnik et al., 2004; Tabashnik et al., 2005; Dhurua and Gujar, 2011; Wan et al., 2012; Ojha et al., 2014; Mohan et al., 2015). Surveys conducted by CICR during 2012-14 showed that pink bollworm larval survival on BG-II was recorded significantly higher in 2012, 2013 and 2014 mainly in Amreli and Bhavnagar districts in Saurashtra (Kranthi, 2015), which led cotton cultivators to shift to other crops.

India has taken a quantum leap in organic cotton production in the recent past. Today India is the world leader in the production of organic cotton contributing to 61 per cent of the global production of 175 thousand metric tonnes. About 117000 farmers are currently engaged in organic cotton production. Ironically, this revolution in organic cotton production is occurring in the $\mathrm{Bt}$ cotton era wherein $80-85 \%$ of the cotton area is under genetically modified (GM) cotton. Thus India is a classical case of coexistence of GM and organic cotton production systems, either by accident or by compulsion. This situation has thrown up several challenges for the entire range of stake holders in the productionsupply chain and has also opened up several avenues for research in organic cotton system (CICR, 2010).

In this paradoxical situation created by combination of factors like development of resistance to chemicals and $B t$ toxins by pink bollworm and increase in organic cotton farming, farmers have left with no choice, either to leave the $B t$ cotton cultivation or to explore the possibility of novel, eco-friendly, long lasting tool which can overcome the above problems. Several workers have tried 
with mass trapping tools (Taneja and Jayaswal, 1983; Karuppuchamy and Balasubramanian, 1990) and mating disruption (Attique et al., 2000; Athanassiou et al., 2002) tools to manage pink bollworm in $B t$ cotton ecosystem. This dynamic and paradigm shift in management strategies satisfies all the bio-safety concern as well as playing a pivotal role in combating insect pests of high-value and damage sensitive crops (Mazumder and Khalequzzaman, 2010). Hence, the present study is aimed at use of Specialized Pheromone and Lure Application Technology (SPLAT) against PBW in Bt cotton ecosystem which has rain fastness property, easy to apply, long lasting and cost effective. So, to assess its feasibility in $B t$ cotton ecosystem its dissipation pattern present investigation was planned.

\section{Materials and Methods}

Pheromone dissipation rates were determined by randomly collecting spoons containing SPLAT-PBW from the $B t$ cotton fields. Spoons (plate 1 and 2) were collected at weekly basis from the day of application to fifth week after application. Such collected spoons were wrapped in aluminium foil and stored in refrigerator. The SPLAT-PBW formulation present in these spoons, which contained gossyplure (mixture of cis, cis and cis, trans isomers of 7, 11- hexadecadienyl acetate) as active ingredient blended with wax and water, was analysed using gas chromatography (GC) at Indian Institute of Technology, Hyderabad.

Sample extraction procedure for estimation of pheromone in SPLAT-PBW by Gas Chromatography (GC)

\section{Preparation of ISTD (Internal Standard)}

$50 \mathrm{mg}$ 12.AC (12.Acetate) was added into $100 \mathrm{ml}$ of standard volumetric flask and made up the volume with ethyl acetate.

\section{Preparation of Calibration standard /} Reference standard (CS/RS)

Empty bottle was weighed and $10 \mathrm{mg}$ reference standard (Pure active) and $20 \mathrm{ml}$ of ISTD was added, weight was noted down.

\section{Sample preparation}

Empty bottle was weighed and $200 \mathrm{mg}$ of lure sample (formulation) and $10 \mathrm{ml}$ of ISTD was added and weight was noted down. The contents were vortexed for proper mixing. Then the mixture was sonicated for 30 minutes.

The solution was incubated for overnight at room temperature. Next day the solution was transferred to $1 \mathrm{ml} \mathrm{GC}$ vials with the use of $0.45 \mu \mathrm{m}$ nylon syringe filter. Then GC was run.

\section{Analysis}

The residual amount of pheromone was calculated from peak area by means of standard curve.

The amount of pheromone released during ageing period was determined by comparing with the amount contained initially versus those remaining after ageing. Weight by per cent of active ingredient (pheromone) was plotted against time (weekly basis) to know the dissipation pattern.

\section{Experimental Results}

The longevity of SPLAT-PBW wax formulation blended with pheromone of pink bollworm, P. gossypiella i.e., (ZZ/ZE) 7, 11Hexadecadienly acetate was studied by Gas chromatographic estimation of residual pheromone remaining in the formulation at different time intervals. 
Table.1 Gas chromatography analysis of SPLAT-PBW formulation at weekly basis in Bt cotton ecosystem

\begin{tabular}{|c|c|c|c|c|c|c|c|c|c|c|c|c|c|}
\hline $\begin{array}{l}\text { Sampling } \\
\text { week }\end{array}$ & A.I & $\begin{array}{c}\text { Sample } \\
\text { weight } \\
\text { (mg) }\end{array}$ & $\begin{array}{c}\text { Wt } \\
\text { of } \\
\text { ISTD }\end{array}$ & $\begin{array}{c}\text { A.I } \\
\text { nominal } \\
3.0 \mathrm{mg}\end{array}$ & $\begin{array}{l}\text { Volum } \\
\text { e of } \\
\text { ISTD } \\
(\mathrm{ml})\end{array}$ & $\begin{array}{c}\text { Conc. } \\
\text { ISTD } \\
\text { sol } \\
(\mathbf{m g} / \mathrm{ml})\end{array}$ & $\begin{array}{l}\text { Actual } \\
\text { mg ISTD } \\
\text { added } \\
(\mathbf{m g})\end{array}$ & $\begin{array}{l}\text { Area } \\
\text { (A.I) }\end{array}$ & $\begin{array}{c}\text { Area } \\
\text { (ISTD) }\end{array}$ & RF & $\begin{array}{c}\text { Per cent } \\
\text { weight of } \\
\text { pheromone } \\
\text { in sample }\end{array}$ & $\begin{array}{c}\text { Average per } \\
\text { cent } \\
\text { pheromone } \\
\text { in sample }\end{array}$ & SD \\
\hline \multirow[t]{3}{*}{ 0 } & GL & 49.30 & 8.781 & 3 & 9.7350 & 0.5 & 4.86752 & 24316 & 33567 & 0.45568 & 3.25912 & \multirow[t]{3}{*}{3.10724} & \multirow[t]{3}{*}{0.14611} \\
\hline & GL & 50.20 & 8.872 & 3 & 9.8359 & 0.5 & 4.91796 & 22589 & 33980 & 0.45568 & 2.96767 & & \\
\hline & GL & 50.20 & 8.845 & 3 & 9.8060 & 0.5 & 4.90299 & 23111 & 33234 & 0.45568 & 3.09495 & & \\
\hline \multirow[t]{3}{*}{1} & GL & 44.17 & 8.960 & 3 & 9.9335 & 0.5 & 4.96674 & 25532 & 52703 & 0.45568 & 2.48230 & \multirow[t]{3}{*}{2.42172} & \multirow[t]{3}{*}{0.06801} \\
\hline & GL & 45.68 & 8.854 & 3 & 9.8160 & 0.5 & 4.90798 & 25333 & 52820 & 0.45568 & 2.34815 & & \\
\hline & GL & 43.80 & 8.827 & 3 & 9.7860 & 0.5 & 4.89302 & 25239 & 52770 & 0.45568 & 2.43471 & & \\
\hline \multirow[t]{3}{*}{2} & GL & 44.00 & 8.807 & 3 & 9.7639 & 0.5 & 4.88193 & 25928 & 64563 & 0.45568 & 2.03041 & \multirow[t]{3}{*}{1.97529} & \multirow[t]{3}{*}{0.06237} \\
\hline & GL & 45.20 & 8.681 & 3 & 9.6242 & 0.5 & 4.81208 & 25345 & 64456 & 0.45568 & 1.90758 & & \\
\hline & GL & 44.80 & 8.822 & 3 & 9.7805 & 0.5 & 4.89024 & 25933 & 64890 & 0.45568 & 1.98787 & & \\
\hline \multirow[t]{3}{*}{3} & GL & 46.60 & 8.869 & 3 & 9.8326 & 0.5 & 4.91630 & 25261 & 74301 & 0.45568 & 1.63444 & \multirow[t]{3}{*}{1.65118} & \multirow[t]{3}{*}{0.02726} \\
\hline & GL & 45.40 & 8.846 & 3 & 9.8071 & 0.5 & 4.90355 & 25345 & 74134 & 0.45568 & 1.68263 & & \\
\hline & GL & 46.80 & 8.821 & 3 & 9.7794 & 0.5 & 4.88969 & 25623 & 74545 & 0.45568 & 1.63647 & & \\
\hline \multirow[t]{3}{*}{4} & GL & 47.10 & 8.888 & 3 & 9.8537 & 0.5 & 4.92683 & 24602 & 80606 & 0.45568 & 1.45482 & \multirow[t]{3}{*}{1.46962} & \multirow[t]{3}{*}{0.02647} \\
\hline & GL & 45.10 & 8.858 & 3 & 9.8204 & 0.5 & 4.91020 & 24456 & 80877 & 0.45568 & 1.50018 & & \\
\hline & GL & 46.00 & 8.848 & 3 & 9.8093 & 0.5 & 4.90466 & 24234 & 80987 & 0.45568 & 1.45385 & & \\
\hline \multirow[t]{3}{*}{5} & GL & 48.38 & 8.661 & 3 & 9.6020 & 0.5 & 4.80100 & 25688 & 92828 & 0.45568 & 1.25134 & \multirow[t]{3}{*}{1.25382} & \multirow[t]{3}{*}{0.00267} \\
\hline & GL & 49.10 & 8.878 & 3 & 9.8426 & 0.5 & 4.92129 & 25435 & 92678 & 0.45568 & 1.25346 & & \\
\hline & GL & 48.30 & 8.808 & 3 & 9.7650 & 0.5 & 4.88248 & 25222 & 92453 & 0.45568 & 1.25664 & & \\
\hline
\end{tabular}


Table.2 Per cent lost and per cent residues of pink bollworm pheromone from SPLAT-PBW at weekly interval

\begin{tabular}{|c|c|c|}
\hline Sampling week & Per cent lost & Per cent residues \\
\hline $\mathbf{0}$ & 0 & 100 \\
\hline $\mathbf{1}$ & 22.06 & 77.94 \\
\hline $\mathbf{2}$ & 36.43 & 63.57 \\
\hline $\mathbf{3}$ & 46.86 & 53.14 \\
\hline $\mathbf{4}$ & 52.7 & 47.3 \\
\hline $\mathbf{5}$ & 59.64 & 40.36 \\
\hline
\end{tabular}

Fig.1 Chromatograms of SPLAT-PBW analysed by GC (at weekly intervals)

Dissipation of pink bollworm pheromone from SPLAT-PBW at weekly interval 0 Week Samples
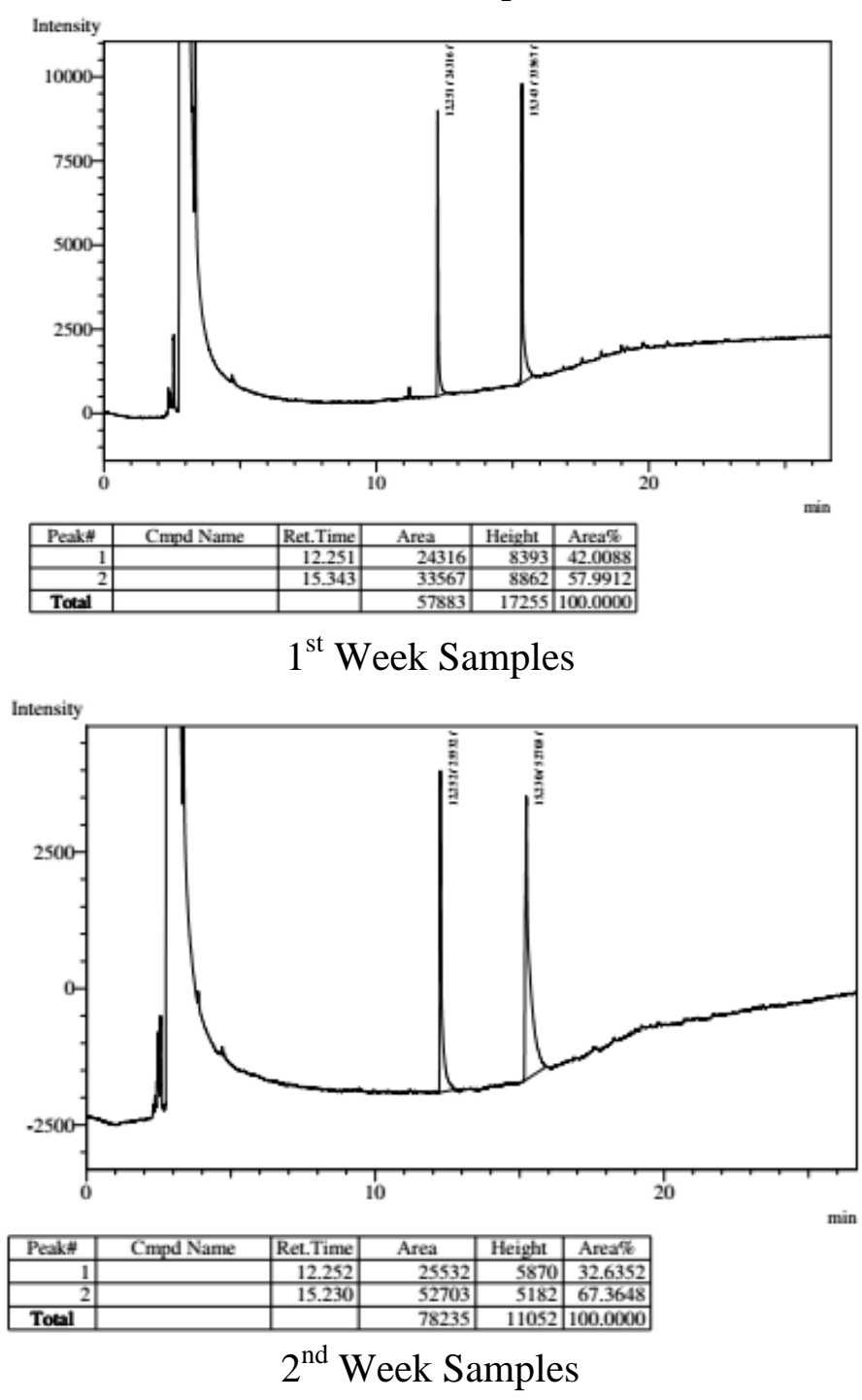

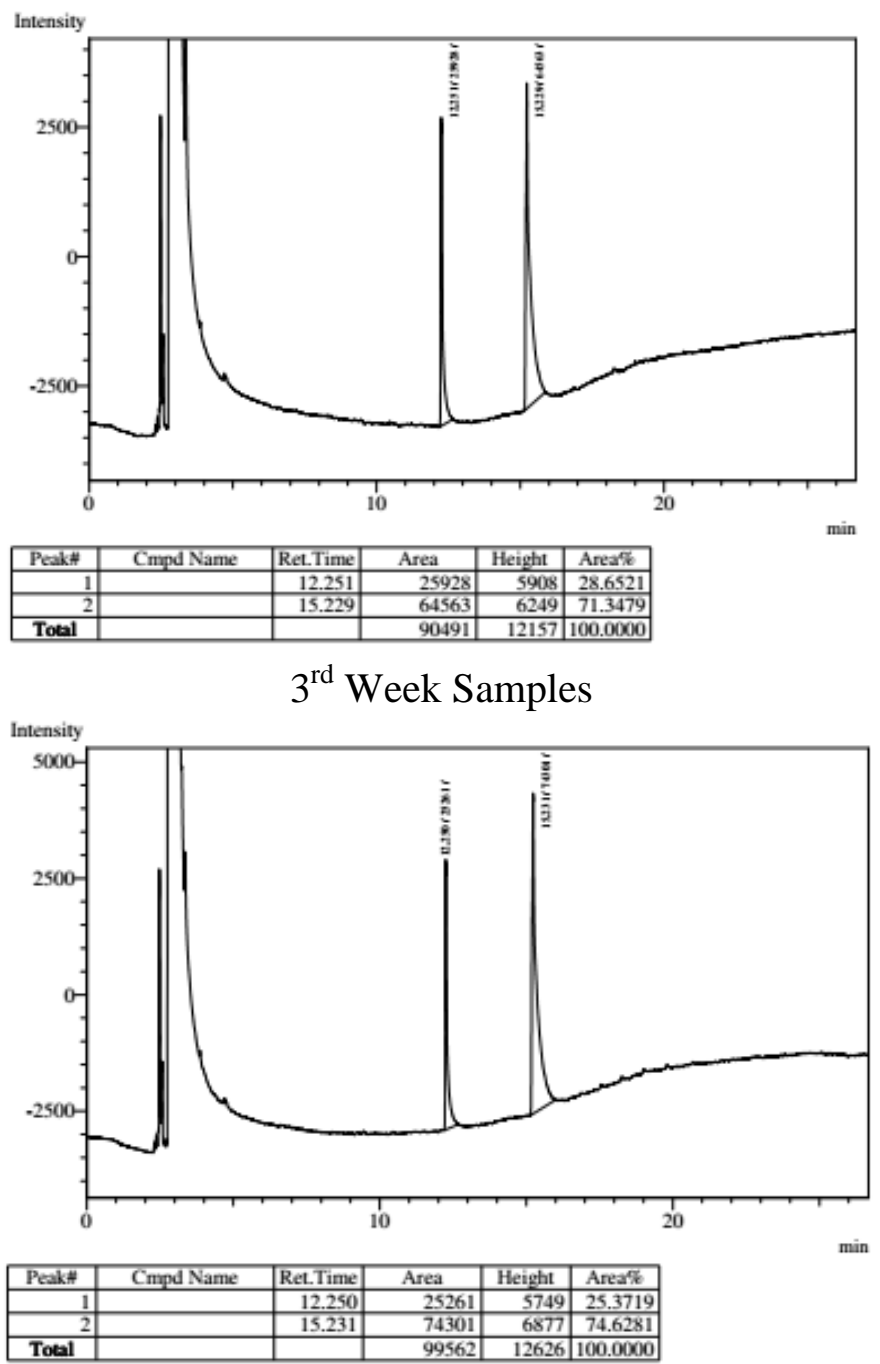

$4^{\text {th }}$ Week Samples
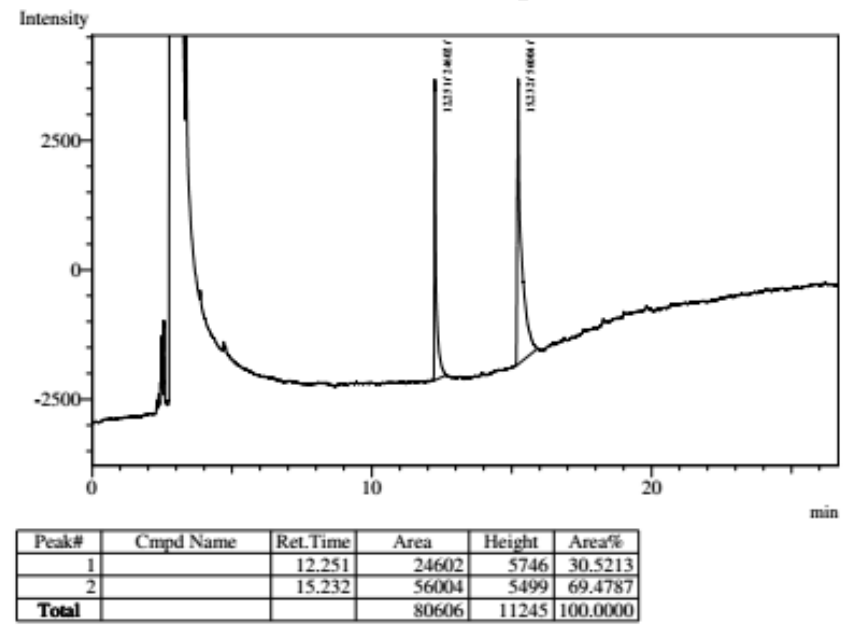

${ }^{\mathrm{h}}$ Week Samples 


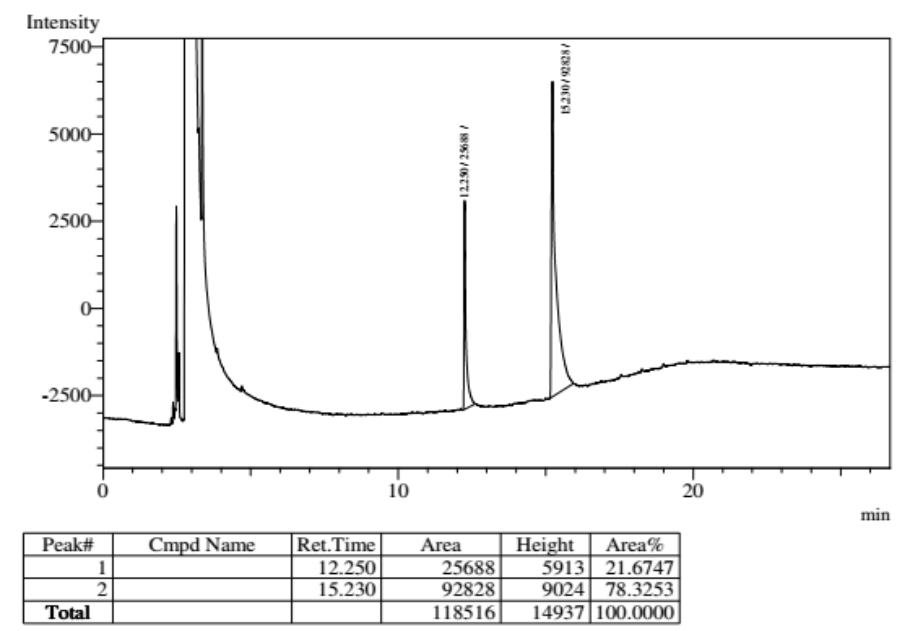

Fig.2 Release profile of gossyplure during five weeks of sampling, analysed using GC

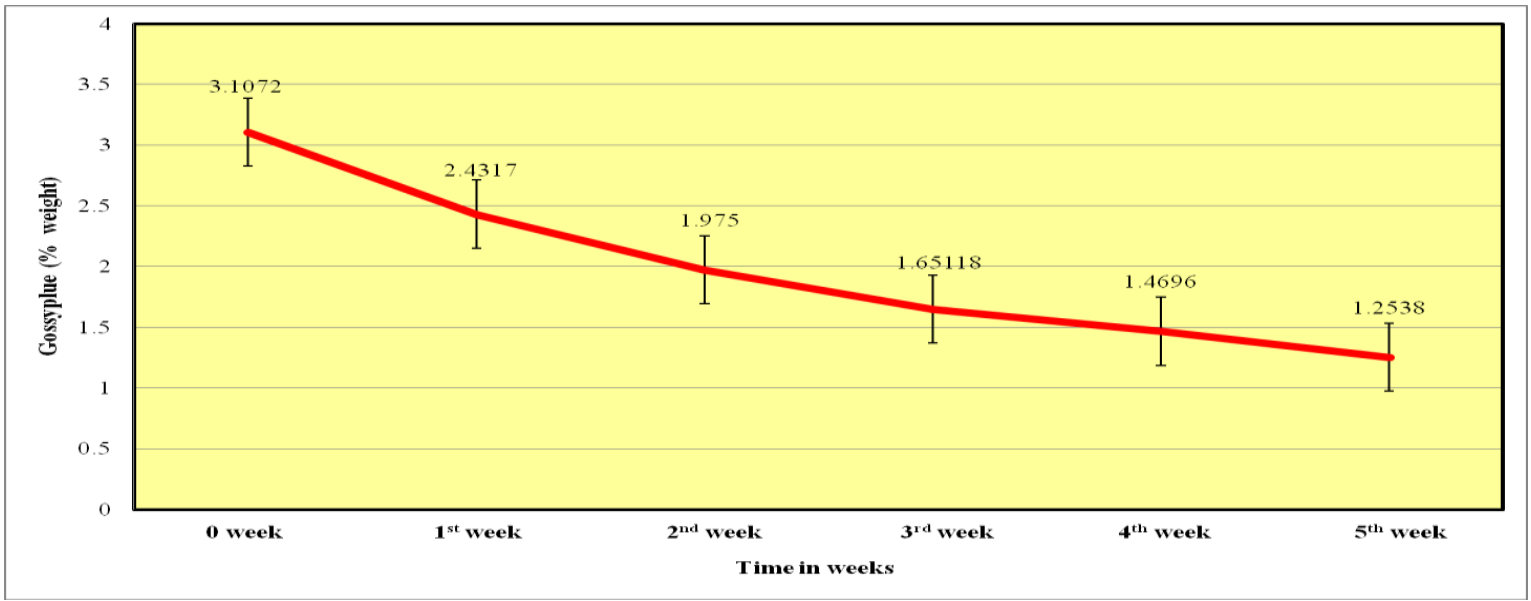

Fig.3 Dissipation pattern of pheromone of pink bollworm, P. gossyiella from SPLAT-PBW formulation in Bt cotton ecosystem

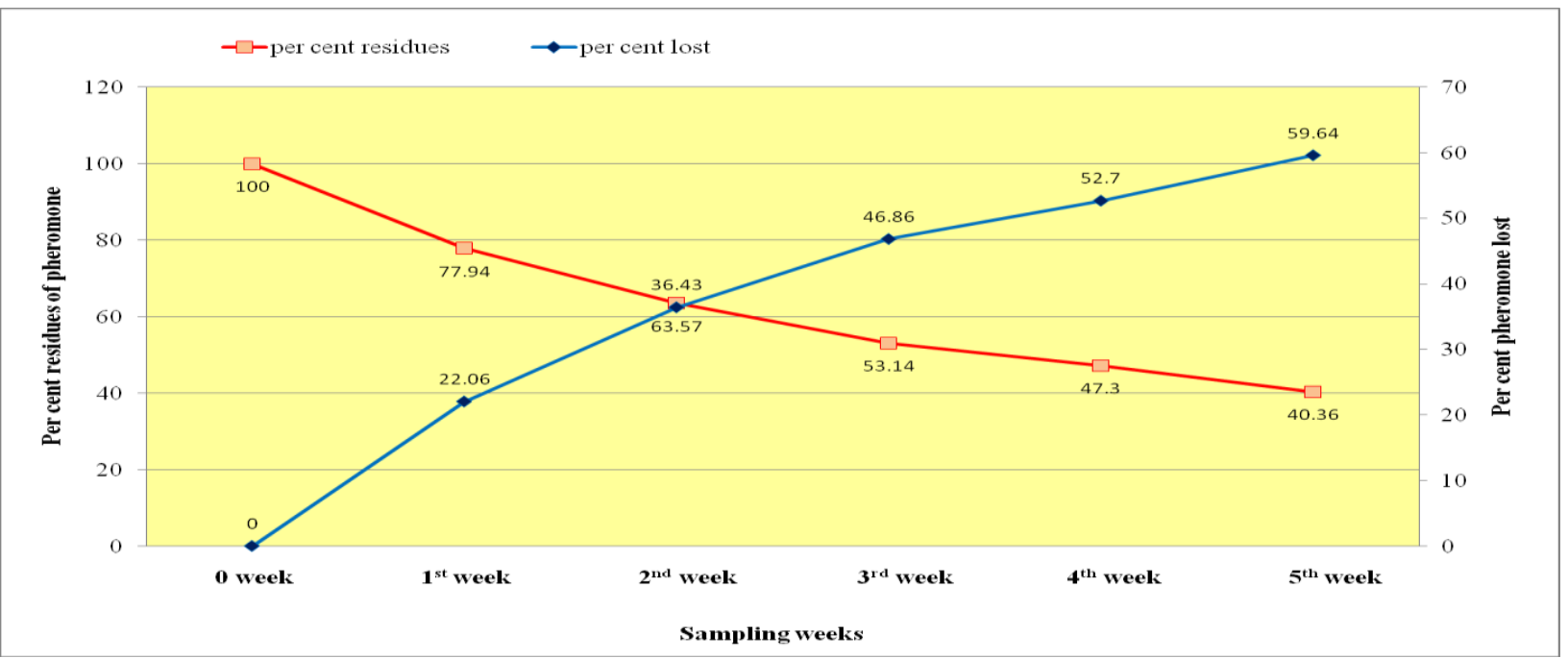


Plate.1 Specialised Pheromone and Lure Application Technhology (SPLAT-PBW) formulation applied with the spoon and placed onto growing part of the plant

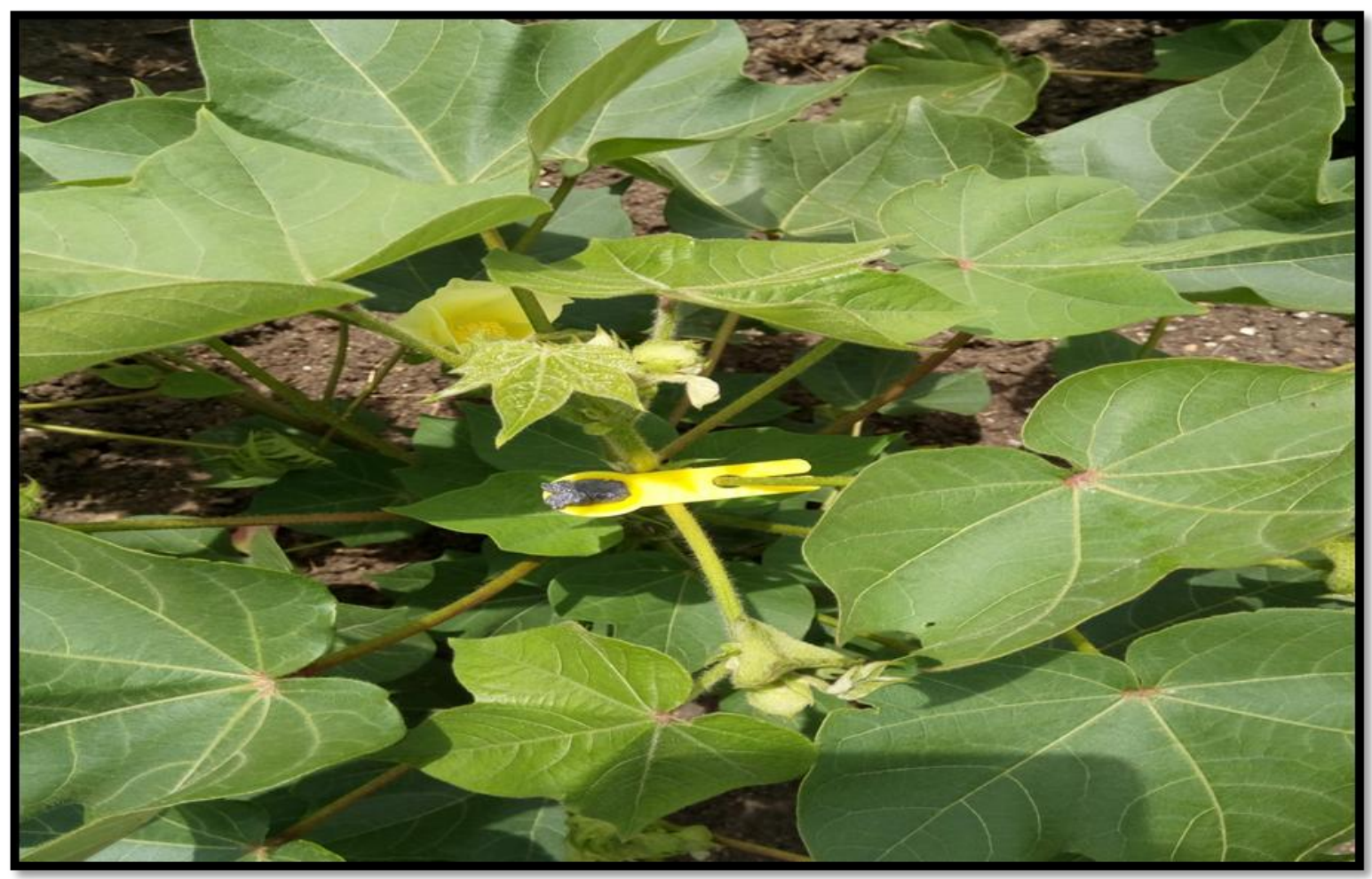

Plate.2 SPLAT applied at the base of leaf petiole in the growing region of plant

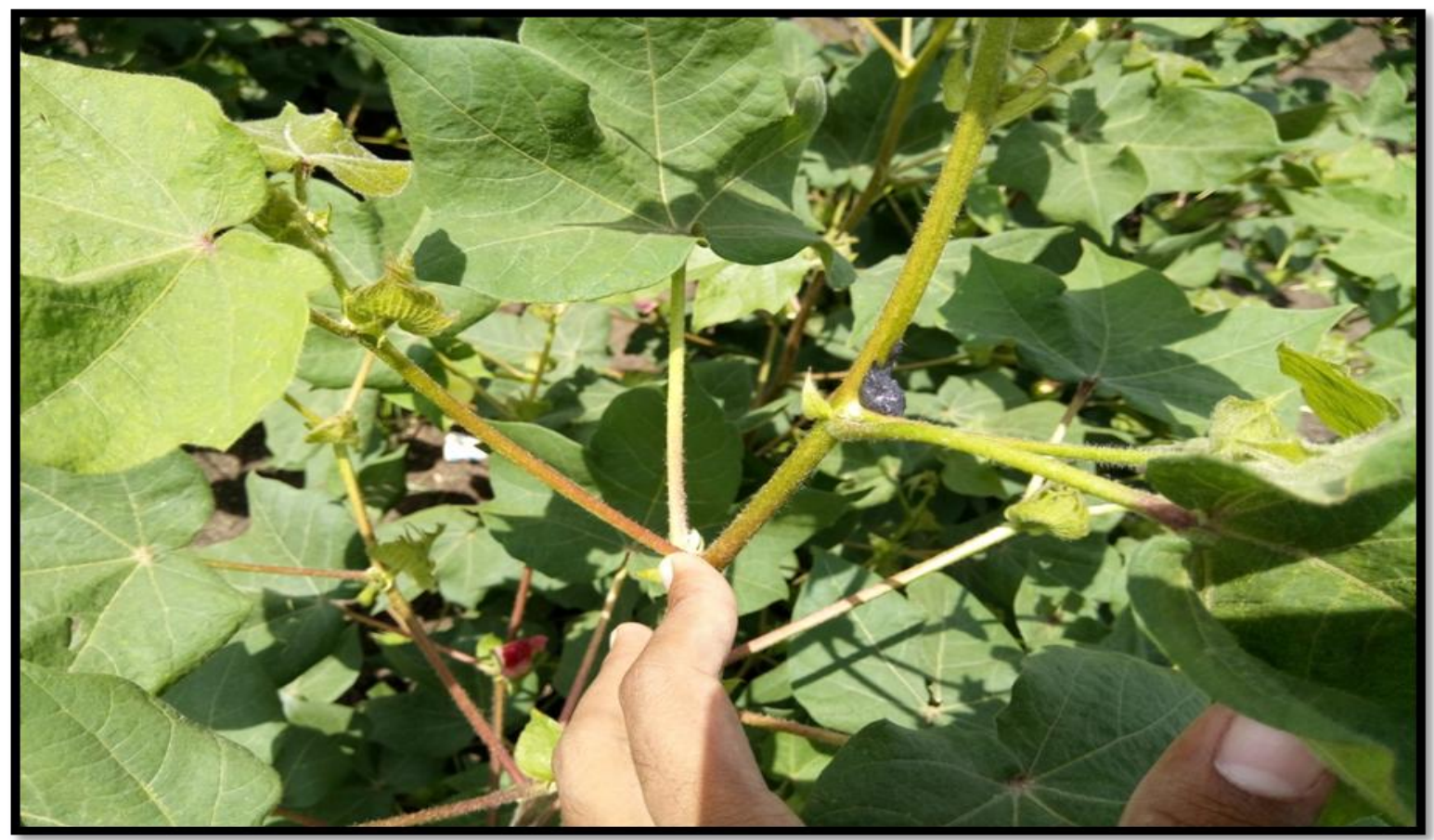


The results revealed that on the day of application there was 3.10724 per cent of pheromone present in the sample, by weight. While, 2.42172, 1.97529, 1.65118, 1.46962 and 1.25382 per cent were the amount of pheromone remaining in the sample by the end of first, second, third, fourth and fifth week respectively (Table 1$)$. The (ZZ/ZE) 7, 11- Hexadecadienly acetate loss curve shows that there was 22.06 per cent loss of original compound within first week and 36.43 per cent loss of this component in next week. After this, there was a slow rate of loss, 46.86 and 52.70 per cent at the end of third and fourth week respectively (Table.2)

Per cent residual amount of pheromone that came out from gas chromatograms of samples (Fig.1) was plotted as function of time. The results revealed that on the day of application there was 3.10724 per cent of pheromone present in the sample, by weight. While, $2.42172,1.97529,1.65118,1.46962$ and 1.25382 per cent were the amount of pheromone remaining in the sample (Fig.2) by the end of first, second, third, fourth and fifth week respectively.By the end of fifth week more than half of the pheromone component was lost from the samples i.e., 59.64 per cent. Which means by the end of fifth week the samples still had 40.36 per cent of initial amount of pheromone left in them. Thus, it is evident that the release of pheromone did not cease until the residues exhausted. (Fig. 3)

Examination of the figures indicated that dissipation is faster in initial days. This may be due to the weaker cohesive forces between pheromone present on the outer surface of the dollop. But with the diffusion of pheromone molecules in the atmosphere, the residual amount of pheromone in dollop decreases this may result in strong adhesive forces between dispenser and pheromone molecules and give a slow release of pheromone with the time (Dixit, 2003)

The results obtained in this study are in contradiction to the lure decay studies carried out by Dixit (2003) on the pheromones of Helicoverpa armigera (Hubner) impregnated on rubber septa, having different components viz., (Z)-11-hexadecenal, (Z)-9-hexadecenal and hexadecanol indicated that by the end of one month only eight per cent of the pheromone component was left in the rubber septa. Whereas, in SPLAT-PBW even by the end of fifth week, there was significant amount of pheromone left i.e., 40.36 per cent. This clearly indicates the slow release mechanism of wax based formulation of pink bollworm, P. gosspiella pheromone SPLATPBW.

In conclusion, the study of dissipation of pheromone from gas chromatographic analysis of SPLAT-PBW formulation has clearly indicated the slow release and long lasting mechanism of the formulation, which has sufficient amount of active ingredient (pheromone) left in it by the end of fifth week. So, once applied, SPLAT-PBW can confuse the male moths of PBW whereby affecting its mating behaviour until 35 days. Hence SPLAT-PBW can be applied safely at an interval of 30-35 days in $B t$ cotton ecosystem to manage the ravaging problem of pink bollworm.

\section{References}

Anonymous 2015. Area, production and productivity of cotton in India: State wise production of cotton. Cotton Advisory Board, Mumbai (Fide: www.cotcorp.gov.in).

Athanassiou, C. G., Buchelos, C. T., Kavallieratos, N. G. andBarbetaki, A. E., 2002, Evaluation of the mating disruption method for the control of the pink 
bollworm Pectinophora gossypiella (Saund.) (Lepidoptera: Gelechiidae) and comparison of this method with insecticidal treatments., IOBC wprs Bulletin: Vol. 25.

Attique, M. R., Ahmad, M. M. and Anmad, Z., 2000, Efficacy of different sex pheromone traps for monitoring and control of pink bollworm, Pectinophora gossypiella (Saunders): Gelechiidae: Lepidoptera. Pak. J. Bio. Sci., 3: 309-312.

Charles, J., Delecluse, A. and Nielsen,L.C., 2000, Entomopathogenic bacteria: from laboratory to field application., Kluwer Academic Publications, Dordrecht, The Netherlands

Choudhary, B. and Gaur, K., 2015, Biotech cotton in India, 2002 to 2014. ISAAA Series of Biotech Crop Profiles. ISAAA: Ithaca, NY.1-34

CICR news letters, central institute for cotton research, Nagpur, July-Sept, 2010, 25(3):1-8

Dhurua, S. and Gujar, G. T., 2011, Fieldevolved resistance to Bttoxin CrylAc in the pink bollworm, Pectinophora gossypiella (Saunders) (Lepidoptera: Gelechiidae), from India. Pest Mgt Sci., 67: 898-903.

Dixit, S., 2003, Persistence and trapping efficiency of pheromone of Helicoverpa armigera (Hubner), Ph.D thesis, G.B. Pant University of Agriculture and Technology, Pantnagar - 263- 145, Uttaranchal, India.

James, C., 2000, Global review of commercialized transgenic crops: 2000. In International Service for the Acquisition of Agri-biotech Applications (ISAAA) Briefs no. 21. ISAAA, Ithaca, N.Y.

Karuppuchamy, P. and Balasubramanian, M., 1990, Field evaluation of gossyplure, the synthetic sex pheromone of Pectinophora gossypiella in Tamil Nadu. Ind. $J$. Entomol., 52: 170-179.

Kranthi, K. R., 2012, Bt cotton questions and answers, Indian Society for Cotton Improvement. Mumbai.,pp. 1-70.

Kranthi, K. R., 2013, Impact of Bt cotton in India, Cotton Association of India. Cotton stastistics and news., 36:1-4.

Kranthi, K. R., 2015, Pink bollworm strikes Btcotton, cotton association of India. Cotton stastistics and news., 35:1-6.

Li, Y. C., Wanf, Q. S., Zhang, G. J., Zhang, S. S., Luo, C. X. and Ding. S. Y., 1997, Insecticide resistance in field strains of Pectinophora gossypiella in China and effects of synergists on deltamehtrin and parathion-methyl activity. Pesti sci., 50: 183-186.

Mazumder, F. and Khalequzzaman, M., 2010, Eggplant shoot and fruit borer Leucinodes orbonalis Guenée male moth catch in sex pheromone trap with special reference of lure elevation and IPM. J. Bio-sci., 18:915.

Mohan, S. K., Ravi, K. C., Suresh, P. J., Sumerford, D. and Graham, P. H., 2015, Field resistance to the Bacillus thuringiensis protein Cry1Ac expressed in Bollgard ${ }^{\circledR}$ hybrid cotton in pink bollworm, Pectinophora gossypiella (Saunders), populations in India. Pest Mgt Sci.,pp.7-10. Ojha, A., Sree, K. S., Sachdev, B., Rashmi, M. A., Ravi, K. C. and Suresh, P. J., 2014,Analysis of resistance to Cry1Ac in field-collected pink bollworm, Pectinophora gossypiella (Lepidoptera: Gelechiidae), populations. GM Crops Food.,5: 280-286.

Patil, S. B., 2003, Studies on management of cotton pink bollworm, Pectionophora gossypiella (Saunders) (Lepidoptera: Gelechiidae), Ph. D. Thesis (unpublished) submitted to University of Agricultural Sciences, Dharwad (India).

Pearson, E. O., 1958, The Insect Pests of Cotton in Tropical Africa, Empire Cotton Growing Corporation, Commonwealth Institute of Entomology, London. 355 pp.

Sabry, K. H. and Nahed, F. A., 2013, Resistance and enzyme assessment of the pink bollworm, Pectinophora gossypiella (Saunders) to spinosad. J. Ani. Pl. Sci., 23: 136-142.

Shelton, A. M.,. Zhao, J. Z. and Roush. R. T., 2002, Economic, ecological, food safety, and social consequences of the deployment 
of Bt transgenic plants. Annu. Rev. Entomol. 47:845-881.

Tabashnik, B. E., Biggs, R. W., Higginson, D. M., Henderson, and Unnithan, D. C., 2005, Association between resistance to $B t$ cotton and cadherin genotype in pink bollworm. J. Eco.Entomol.98: 635-644.

Tabashnik, B. E., Liu, Y. B., Unnithan, D. C., Carriere, Y., Dennehy, T. J. And Morin, S., 2004, Shared genetic basis of resistance to Bt toxin CrylAc in independent strains of pink bollworm. J. Eco. Entomol., 97: 721726.
Taneja, S. L. and Jayaswal A. P., 1983, Factors affecting male pink bollworm moth catches in gossyplure baited traps. Indian $\mathrm{J}$. Pl. Prot., 11: 78-83.

Wan, P., Huang, Y., Wu, H., Huang, M., Cong, S. and Tabashnik, B. E., 2012, Increased frequency of pink bollworm resistance to $B t$ toxin Cry1Ac in China. PLoS ONE., 7: 29975.

Narayanan, E. S., 1962, Biology and method of control of some important insect pests of cotton in India. Indian Central Cotton Committee Publication, Bombay, p. 44.

\section{How to cite this article:}

Shrinivas, A.G. Sreenivas, S.G. Hanchinal, Sujay Hurali and Beldhadi, R.V. 2019. Dissipation of Pheromone from Dispensers of Specialized Pheromone and Lure Application Technology (SPLAT-PBW) Formulation used against Pink Bollworm, Pectinophora gossypiella (Saunders) (Lepidoptera: Gelechiidae) in Bt Cotton Ecosystem. Int.J.Curr.Microbiol.App.Sci. 8(02): 23362346. doi: https://doi.org/10.20546/ijcmas.2019.802.272 